\title{
PENGARUH KURS, SUKU BUNGA, DAN DIVIDEN PERSHARE TERHADAP HARGA SAHAM PADA SEKTOR PERBANKAN YANG TERDAFTAR DIBURSA EFEK INDONESIA TAHUN 2013- 2017
}

\author{
Atika Riziqyani, Gunistiyo, dan NikenWahyu C \\ Program Studi Manajemen \\ Fakultas Ekonomi Universitas Pancasakti
}

\begin{abstract}
The effect of exchange rate, interest rate and dividend of share price on banking sector which is listed in Indonesia Stock Exchange year 2013-2017. Essay. Tegal: Faculty of Economics and Business Universitas Pancasakti Tegal,2018. The purpose of this study is to determine the ability of investors in considering stock prices in the banking sector in 2013-2017. Hypothesis in this research is 1) exchange rate effect on stock price. 2) interest rates affect the stock price. 3) dividend pershare effect on stock price. 4) exchange rate, interest rate and dividend pershare simultaneously affect the stock price. The population used in this study is a banking company that publishes stock prices listed on the Indonesia Stock Exchange in 2013-2017. The sample in this research are 21 banking companies. With technique of sampling using purposive sampling. The data in this research is quantitative data. Sources of data in this study are secondary sources obtained from the share price of an annual banking company published in Indonesia Stock Exchange period 2013-2017. Data collection techniques using documentation techniques. Data analysis method using descriptive statistic, classical assumption test, simple linear regression analysis, multiple linear regression analysis and coefficient of determination, then obtained the result of research that the exchange rate does not have a significant effect on stock prices, the interest rate does not significantly influence the stock price, against stock price, exchange rate, interest rate and dividend pershare have significant effect to stock price.
\end{abstract}

Keywords: Rate, Interest Rate, Dividend Pershare, Stock Price

\section{PENDAHULUAN}

Perkembangan pasar modal yang pesat memiliki peran penting dalam meningkatkan pertumbuhan perekonomian, karena pasar modal memiliki dua fungsi, yaitu fungsi ekonomi dan fungsi keuangan. Dalam melaksanakan fungsi ekonomi, pasar modal menyediakan fasilitas untuk memindahkan dana dari pihak yang surplus dana kepada pihak yang membutuhkan dana. Sementara dalam melaksanakan fungsi keuangan, pasar modal menyediakan dana yang dibutuhkan oleh pihak yang memerlukan dana, dan pihak yang memiliki kelebihan dana dapat ikut terlibat dalam kepemilikan perusahaan.

Dalam pasar modal terdapat instrumen yang diperdangangkan. Yang dimaksud dengan instrumen pasar modal adalah semua jenis surat berharga (securities) yang diperdagangkan di pasar modal. Jenis-jenis surat berharga yang diperdagangkan dipasar modal Indonesia terdiri dari surat berharga yang bersifat ekuitas, surat berharga 
yang bersifat utang, surat berharga derivatif, dan surat berharga berupa reksa dana (Sabar Warsini, 2009).

Saham (stock) salah satu instrumen pasar keuangan yang paling populer. Menerbitkan saham merupakan salah satu pilihan perusahaan ketika memutuskan untuk pendanaan perusahaan. Pada sisi yang lain, saham merupakan intrumen investasi yang banyak dipilih oleh investor karena saham mampu memberikan tingkat keuntungan yang menarik.

Saham merupakan penyertaan atau kepemilikan sesornag atau badan dalam suatu perusahaan. selembar saham adalah selembar kertas yang menerangkan bahwa pemilik kertas tersebut yang menerbitkan kertas (saham) tersebut. Selembar saham mempunyai nilai atau harga. Harga saham setiap perusahaam tidak sama, harganya akan berbeda-beda. Hal itu ditentukan oleh pendapatan perusahaan dan potensi pertumbuhan keuntungan perusahaan.

Fenomena yang terjadi terhadap harga saham di perusahaan pertambangan menurun akibat buruknya kinerja keungan. Salah satunya terjadi di PT Bumi Resources Tbk, managing Research Indosurya Asset Management Reza Priyambada menilai anjloknya harga saham PT Bumi Resources Mineral dipicu oleh kinerja keuangan perseorangan. Anjloknya saham BUMI hingga 14,6 persen akibat sentimen negatif investor pasca perusahaan grub Bakrie tersebut melansir kinerja keuangan semester pertama 2012. Pada paruh pertama 2012, BUMI mencatat kerugian bersih senilai US\$ 231,68 juta. Menurut Reza saham BUMI bisa saja rebound lagi, jika ada komitmen dari manajemen untuk memperbaiki kinerja dan melunasi utang. (http://m.tempo.co/read/news/2012/08/2 8/088426077/kinerja-buruk-saham-bumi anjlok).
PT Vale Indonesia Tbk (INCO) mencatat penurunan laba di tahun 2013 hingga 42,7 persen dibanding tahun 2012. Penurunan tersebut seiring dengan turunnya pendapatan yang dihasilkan persero. Research Analyst PT Buana Capital Alfred Nainggolan mengatakan menurunnya laba tersebut membuat harga saham INCO akan mengalami penurunan. Penurunan laba INCO ini seiring dengan turunnya pendapatan yang dihasilkan perseroan pada tahun 2013, yakni USD921,6 juta dibandingkan periode sebelumnya USD967,3 juta. Sementara itu, saham INCO ditutup melemah hingga 3, 05 persen atau 75 poin ke Rp.2.385. dalam pergerakan selama 52 minggu, saham INCO bergerak di kisaran Rp.1.770-Rp2.850. (http://idsaham.com/ news-saham-labaturun-jadi-sentimen-negatif-saham-

INCO-404590.html)

Harga saham adalah nilai nominal penutupan (closing price) dari penyertaan atau pemilikan seseorang atau badan dalam suatu perusahaan atau perseroan terbatas yang berlaku secara reguler di pasar modal di Indonesia. Jika perusahaan mencapai prestasi yang baik, maka saham perusahaan tersebut akan banyak diminati oleh banyak investor. Prestasi baik yang dicapai perusahaan dapat dilihat di dalam laporan keuangan yang dipublikasikan oleh perusahaan. Penentuan harga saham yang seharusnya telah dilakukan oleh setiap analis keuangan dengan tujuan untuk bisa memperoleh tingkat keuntungan yang menarik. Harga saham dapat dibentuk interaksi dari penjual dan pembeli dengan harapan dapat mendapatkan keuntungan yang diharapkan dari membeli saham tersebut. Sehingga para investor harus dapat mempunyai informasi yang dibutuhkan dalam menganalisis dan mengambil keputusan menjual maupun membeli saham. 
Di Indonesia kurs valas mengalami perubahan setiap waktu, ada kalanya Rupiah menganut mata uang asing pada saat kondisi Indonesia stabil atau cenderung membaik dari kondisi sebelumnya, penguatan nilai tukar mata uang suatu negara bisa menekan laju inflasi. Sebaliknya Rupiah akan melemah terhadap mata uang asing pada saat kondisi Indonesia memburuk. Apabila harga-harga barang dan sektor jasa cenderung mengalami kenaikan maka disebut dengan inflasi. Oleh sebab itu untuk mencegah makin meningkatnya inflasi maka jumlah mata uang yang beredar harus sesuai dengan kebutuhan, sehingga kestabilan nilai tukar bisa dijaga (permintaan agregat).

\section{TINJAUAN PUSTAKA}

\section{Pasar modal}

Menurut Marzuki Usman (1989), pasar modal adalah pelengkap di sektor keuangan terhadap dua lembaga lainnya yaitu bank dan lembaga pembiayaan. Pasar modal memberikan jasanya yaitu menjembatanu hubungan antara pemilik modalam dalam hal ini disebut sebagai pemodal (investor) dengan peminjaman dana dalam hal ini disebut dengan nama emiten (perusahaan yang go public). Para pemodal meminta instrumen pasar modal untuk keperluan investasi portofolio sehingga pada akhirnya dapat memaksimumkan penghasilan. Instrumen pasar modal itu terbagi atas dua kelompok besar yaitu instrumen pemilik (equity) seperti saham dan instrumen utang (obligasi/bond) seperti obligasi perusahaan, obligasi langganan, obligasi yang dapat dikonversikan dengan menjadi saham dan sebagainya.

\section{Harga Saham}

Pengertian harga saham menurut Jogiyanto (2010), adalah: harga saham terjadi dipasar bursa pada saat tertentu yang ditentukan oleh pelaku pasar dan ditentukan oleh permintaan dan penawaran saham yang bersangkutan dipasar modal. Menurut Widoatmojo (1996) dalam Satria (2008) harga saham dapat dibedakan menjadi 3 (tiga):

Harga Nominal

Harga yang tercantum dalam sertifikat saham yang ditetapkan oieh emiten untuk menilai setiap lembar saham yang dikeluarkan. Besarnya harga nominal memberikan arti penting saham karena dividen minimal biasanya ditetapkan berdasarkan nilai nominal.

Harga Perdana

Harga ini merupakan harga pada waktu harga saham tersebut dicatat di bursa efek. Harga saham pada pasar perdana biasanya ditetapkan oleh penjamin emisi (underwriter) dan emiten. Dengan demikian akan diketahui berapa harga saham emiten itu akan dijual kepada masyarakat biasanya imtuk menentukan harga perdana.

Harga pasar

Kalau harga perdana merupakan harga jual dari perjanjian emisi kepada investor, maka harga pasar adalah harga jual dari investor yang satu dengan investor yang lain. Harga ini terjadi setelah saham tersebut dicatatkan di bursa. Transaksi disini tidak lagi melibatkan emiten dan penjamin emisi harga ini yang disebut sebagai harga di pasar sekunder dan harga inilah yang benar benar mewakili harga perusahaan penerbitnya, karena pada transaksi di pasar sekunder, kecil sekali terjadi negosiasi harga investor dengan perusahaan penerbit. Harga yang setiap hari diumumkan di surat kabar atau media lain adalah harga pasar.

\section{Kurs}

Nilai tukar didefinisikan sebagai harga dari setiap mata uang domestik terhadap mata uang negara lain 
(Levich, 2001). Menurut Fabozzi dan Modigliani (1995) mendefinisikan nilai tukar mata uang sebagai jumlah dari mata uang seari negara yang dapat ditukar per unit mata uang negara lain, atau dengan kata lain harga suatu mata uang terhadap mata uang lain.

Heru (2008) manyatakan bahwa nilai tukar mencerminkan keseimbangan permintaan dan penawaran terhadap mata uang dalam negeri maupun mata uang asing. Merosotnya nilai tukar rupiah merefleksikan menurunnya permintaan masyarakat terhadap mata uang rupiah karena menurunnya peran perekonomian nasional atau karena meningkatnya permintaan mata uang asing sebagai alat pembayaran internasioanl. Semakin menguat kurs rupiah sampai batas tertentu berarti menggambarkan kinerja dipasar uang semakin menunjukan perbaikan. Sebagai dampak meningkatnya laju inflasi maka nilai tukar domestik semakin melemah terhadap mata uang asing. Hal ini dapat mengakibatkan menurunnya kinerja suatu perusahaan dan investasi di pasar modal menjadi berkurang.

Menurut Sukirno (2006), kurs adalah jumlah uang domestik yang dibutuhkan, yaitu banyaknya rupiah yang dibutuhkan untuk memperoleh satu unit mata uang asing. Nilai tukar atau lazim juga disebut kurs valuta dalam berbagai transaksi ataupun jual beli valuta asing, dikenal ada empat jenis yakni (dornbusch dan fischer, 1992) :

Selling rate (kurs jual), yakni kurs yang ditentukan oleh suatu bank untuk penjualan valuta asing tertentu pada saat tertentu.

Middle rate (kurs tengah), adalah kurs tengah antara kurs jual dan kurs beli valuta asing terhadap mata uang nasional, yang ditetap- kan oleh Bank Central pada suatu saat tertentu.

Buying rate (kurs beli), adalah kurs yang ditentukan oleh suatu bank untuk pembelian valuta asing tertentu pada saat tertentu. Flat rate (kurs flat), adalah kurs yang berlaku dalam transaksi jual beli bank notes dan traveller chaque, dimana dalam kurs tersebut sudah diperhitungkan promosi dan biaya-biaya lainnya.

\section{Suku Bunga}

Menurut Judisseno (2002:80), suku bunga adalah penghasilan yang diperoleh oleh orang-orang yang memberikan kelebihan uangnya atau surplus spending unit untuk digunakan sementara waktu oleh orang-orang yang membutuhkan dan menggunakan uang tersebut untuk menutupi kekurangannya atau deficit spending units.

Menurut Novianto (2011:22), berdasarkan bentuknya suku bunga dibagi menjadi dua jenis, yaitu:

Suku bunga nominal adalah suku bunga dalam nilai uang. Suku bunga ini merupakan nilai yang dapat dibaca secara umum. Suku bunga ini menunjukkan sejumlah rupiah untuk setiap satu rupiah yang diinvestasikan.

Suku bunga riil adalah suku bunga yang telah mengalami koreksi akibat inflasi dan didefinisikan sebagai suku bunga nominal dikurangi laju inflasi.

\section{Dividen pershare}

Dividen per Share adalah dividen per lembar saham. Dividen per lembar saham merupakan keuntungan yang dibagikan kepada pemegang saham oleh perusahaan sebanding atau sesuai dengan jumlah saham yang dimiliki dan dapat berupa dividen tunai atau dividen saham, 
tetapi yang lebih sering dibagikan adalah dividen tunai (Pratinah dan Prabandaru, 2012).

Menurut Warsono (2002: 37) dividen per lembar saham (dividend per share) merupakan perbandingan antara besarnya dividen total yang dibayarkan perusahaan dengan jumlah saham yang beredar. Besarnya hasil perhitungan dividen per lembar menunjukkan besarnya distribusi sebagian laba yang dihasilkan perusahaan setiap unit saham kepada para pemegang sahamnya. Dividend per share dapat dirumuskan sebagai berikut (Warsono, 2002: 37).

\section{Kerangka pemikiran}

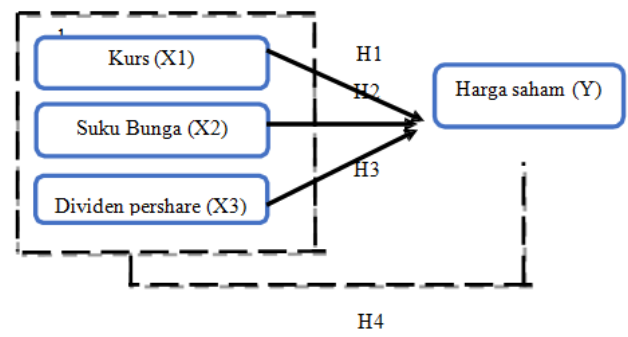

Gambar 1. Kerangka pemikiran

Keterangan :

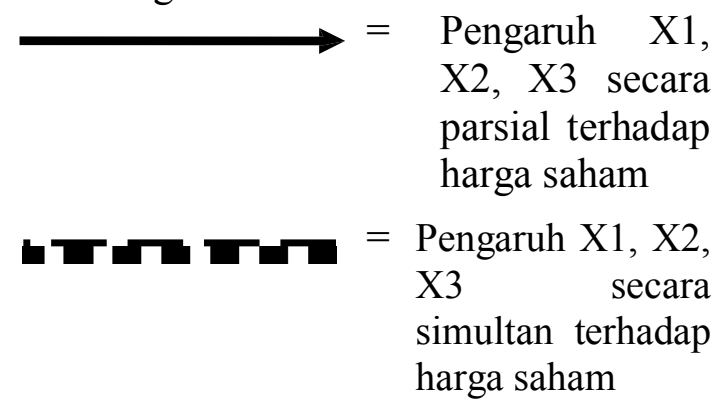

\section{Perumusan hipotesis}

Hipotesis merupakan suatu ide untuk mencari fakta yang harus dikumpulkan. Hipotesis adalah suatu pernyataan sementara atau dugaan yang paling memungkinkan yang masih harus dicari kebenarannya. Mengacu pada rumusan masalah, penelitian terdahulu, dan kerangka pemikiran tersebut, maka hipotesis yang diajukan dalam penelitian ini adalah sebagai berikut: 1. Terdapat pengaruh kurs terhadap harga saham. 2 . Terdapat pengaruh suku bunga terhadap harga saham. 3. Terdapat perngaruh dividen pershare terhadap harga saham.

Terdapat pengaruh kurs, suku bunga dan dividen pershare secara simultan terhadap harga saham.

\section{METODE PENELITIAN}

\section{Populasi sampel}

Populasi dalam penelitian ini adalah perusahaan-perusahaan sektor perbankan yang terdaftar di Bursa Efek Indonesia Tahun 2013-2017. Populasi dalam penelitian ini sebanyak 45 perusahaaan perbankan. Dan didapatkan 29 sample perbankan yang terdaftar di Bursa Efek Indonesia.

Dengan pertimbangan arah tujuan penelitian, kriteria yang ditetapkan adalah sebagai berikut:

Perusahaan yang listed pada Bursa Efek Indonesia paling tidak pada tahun 2013 dan tetap terdaftar sampai dengan tahun 2017.

Mempunyai data harga saham perbulan selama periode 2013-2017. 
Tabel 3. Sampel Perusahaan Perbankan periode 2013-2017

\begin{tabular}{|c|c|c|}
\hline No & Kode & Nama Bank \\
\hline 1. & AGRO & Bank Rakyat Indonesia Agroniaga Tbk \\
\hline 2. & BABP & Bank MNC Internasional Tbk \\
\hline 3. & BACA & Bank Capital Indonesia Tbk \\
\hline 4. & BBCA & Bank Central Asia Tbk \\
\hline 5. & BBKP & Bank Bukopin Tbk \\
\hline 6. & BBNI & Bank Negara Indonesia (persero) Tbk \\
\hline 7. & BBNP & Bank Nusantara Parayangan Tbk \\
\hline 8. & BBRI & Bank Rakyat Indonesia (persero) Tbk \\
\hline 9. & BBTN & Bank Tabungan Negara (persero) Tbk \\
\hline 10. & BDMN & Bank Danamon Indonesia Tbk \\
\hline 11. & BKSW & Bank QNB Indonesia Tbk \\
\hline 12. & BMRI & Bank Mandiri (persero) Tbk \\
\hline 13. & BNGA & Bank Cimb Niaga Tbk \\
\hline 14. & BNII & Bank Maybank Indonesia Tbk \\
\hline 15. & BNLI & Bank Permata Tbk \\
\hline 16. & BSIM & Bank Sinarmas Tbk \\
\hline 17. & INPC & Bank Artha Graha Internasioanal Tbk \\
\hline 18. & MAYA & Bank Mayapada Internasional Tbk \\
\hline 19. & MEGA & Bank Mega Tbk \\
\hline 20. & NISP & Bank OCBC NISP Tbk \\
\hline 21. & SDRA & Bank Woori Saudara Indonesia \\
\hline
\end{tabular}

\section{Metode analisis data}

\section{Uji Asumsi Klasik}

Uji asumsi klasik terdiri dari uji normalitas, uji multikolinieritas, heterokedastisitas dan autokorelasi. Berikut ini pengujian asumsi klasik:

\section{Uji Normalitas}

Uji normalitas bertujuan untuk menguji apakah dalam model regresi, variabel pengganggu atau residual memiliki distribusi normal. Seperti diketahui bahwa uji $t$ dan $F$ mengasumsikan bahwa nilai residual mengikuti distribusi normal. Kalau asumsi ini dilanggar maka uji statistik menjadi tidak valid untuk jumlah sampel kecil (Ghozali, 2011: 160).

\section{Uji Multikoliniearitas}

Menurut (Ghozali, 2011: 105) uji multikolonieritas bertujuan untuk menguji apakah model regresi ditemukan adanya korelasi antar variabel bebas (independen). Model regresi yang baik seharusnya tidak terjadi korelasi diantara variable independent. Jika variabel independen saling berkorelasi, maka variabelvariabel ini tidak orthogonal. Variabel orthogonal adalah variabel independen yang nilai korelasi antar sesama variabel independen sama dengan nol.

\section{Uji Autokorelasi}

Uji autokorelasi bertujuan menguji apakah dalam model regresi linier ada korelasi antara kesalahan pengganggu pada periode $t$ dengan kesalahan pengganggu pada periode t-1 (sebelumnya). Jika terjadi korelasi, maka dinamakan ada problem auto- 
korelasi. Autokorelasi muncul karena observasi yang berurutan sepanjang waktu berkaitan satu sama lainnya (Ghozali, 2011: 110).

\section{Uji Heteroskedastisitas}

Uji heteroskedatisitas bertujuan menguji apakah dalam model regresi terjadi ketidaksamaan varian dari residual satu pengamatan ke pengamatan yang lain. Jika varian dari residual satu pengamatan ke pengamatan lain tetap, maka disebut homoskedastisitas dan jika berbeda disebut heteroskedastisitas. Model regresi yang baik adalah yang homoskedastisitas atau tidak terjadi Heteroskedastisitas. Model regresi yang baik adalah yang Homoskedastisitas atau tidak terjadi Heteroskedastisitas. Kebanyakan data crossection mengandung situasi heteroskedastisitas karena data ini menghimpun data yang mewakili berbagai ukuran (kecil, sedang, dan besar) (Ghozali, 2011: 139).

\section{Analisis Regresi Linier Sederhana}

Regresi sederhana didasarkan pada hubungan fungsional ataupun kausal. Satu variabel independen dengan satu variabel dependen.

Dimana :

$\mathrm{Y}=$ Subyek dalam variabel dependen yang diprediksikan.

$\mathrm{a}=$ Harga $\mathrm{Y}$ ketika harga $\mathrm{X}=0$ (harga konstan)

$\mathrm{b}=$ Angka arah atau koefisien regresi, yang menunjukkan angka peningkatan ataupun penurunan variabel dependen yang didasarkan perubahan variabel independen. Bila $(+)$ arah garis naik, dan bila (-) maka arah garis turun.

$\mathrm{X}=$ Subyek pada variabel independen yang mempunyai

nilai tertentu. $e=$ Standard eror

\section{Uji Signifikansi Koefisien Regresi Linier Sederhana}

Yaitu untuk mengetahui apakah variabel independen/bebas dalam penelitian ini adalah kurs, suku bunga dan dividen pershare secara individual berpengaruh terhadap variabel dependen/terikat yaitu harga saham.

\section{Analisis Regresi Linier Berganda}

Analisis regresi adalah analisis ketergantungan dari satu atau lebih variabel bebas terhadap satu variabel tergantung dengan tujuan untuk menduga atau memprediksi nilai rata-rata populasi berdasarkan nilai variabel bebasnya. Sedangkan pada kenyataannya dimana satu variabel terikat dapat dipengaruhi oleh dua atau lebih variabel bebas, sehingga analisis regresi sederhana diperluas menjadi analisis regresi berganda. Analisis yang digunakan dalam penelitian ini untuk mengukur pengaruh variabel bebas terhadap variabel terikat dan menduga besar dan arah dari pengaruh tersebut serta mengukur derajat keeratan hubungan antara variabel harga saham dengan kurs, suku bunga dan dividen pershare. Adapun bentuk umum dari regresi linier berganda adalah sebagai berikut:

$$
\begin{aligned}
\mathbf{Y}=\mathbf{a}+ & \mathbf{b 1} \mathbf{X} 1+\mathbf{b} 2 \mathbf{X}_{2}+\mathbf{b} 3 \mathbf{X} 3+\mathbf{E} \\
\mathrm{a}= & \text { Konstanta } \\
\mathrm{b}= & \text { Koefisien regresi dari setiap } \\
& \text { variabel independen } \\
\mathrm{X}_{1}= & \text { Variabel bebas pertama } \\
& \text { (kurs/nilai tukar) }
\end{aligned}
$$




$$
\begin{aligned}
\mathrm{X}_{2}= & \begin{array}{l}
\text { Variabel bebas } \\
\text { (suku bunga) }
\end{array} \\
\mathrm{X}_{3}= & \begin{array}{l}
\text { Variabel bebas ketiga } \\
\text { (dividen pershare) }
\end{array} \\
\mathrm{E}= & \begin{array}{l}
\text { Variabel eksternal/ variabel } \\
\text { lain yang tidak diteliti } \\
\text { (standar error) }
\end{array}
\end{aligned}
$$

\section{Uji Signifikan Koefisien Regresi Linier Berganda}

Pengujian terhadap hipotesis yang dilakukan dalam penelitian ini dilakukan dengan menggunakan uji F. Uji statistik $F$ pada dasarnya menunjukan apakah semua variabel independen atau bebas yang dimasukan dalam model mempunyai pengaruh secara bersama-sama terhadap variabel dependen/terikat (Ghozali, 2011:98).

\section{Koefisien Determinasi $\left(\mathbf{R}^{2}\right)$}

Koefisien determinan $\left(\mathrm{R}^{2}\right)$ mengukur seberapa jauh kemampuan model dalam menerangkan variasi variabel dependen. Nilai R2 mempunyai interval antara 0 sampai 1 $(0 \leq \mathrm{R} 2 \leq 1)$. Semakin besar R2 (mendekati 1), semakin baik hasil untuk model regresi tersebut dan semakin mendekati 0 , maka variabel independen secara keseluruhan tidak dapat menjelaskan variabel dependen.
Nilai R2 yang kecil berarti kemampuan variabel-variabel independen dalam menjelaskan variasi variabel dependen amat terbatas. Nilai yang mendekati satu berarti variabel-variabel indepanden memberikan hampir semua informasi yang dibutuhkan untuk memprediksi variasi variabel dependen (Ghozali, 2011:97).

\section{HASIL DAN PEMBAHASAN \\ Uji Asumsi Klasik}

Uji Normalitas

Hasil Uji Kolmogrov-Smirnov Test

One-Sample Kolmogorov-Smirnov Test

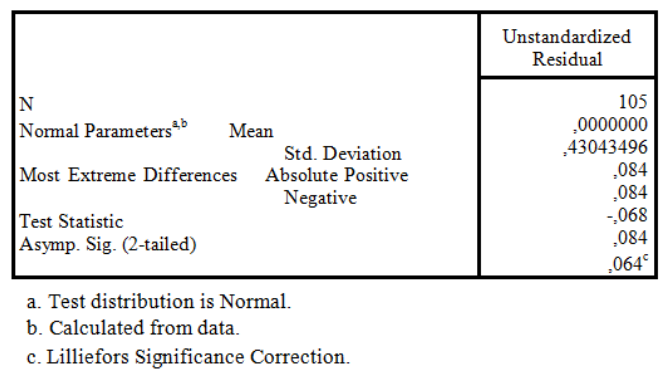

Berdasarkan hasil pada tabel diatas, menunjukkan bahwa data normal. Hal ini ditunjukkan dengan nilai KolmogrovSmirnov adalah 0,084 dan signifikan sebsar 0,064. Hal ini berarti data residual terdistribusi secara normal, karena nilai signifikansinya lebih dari 0,05.

\section{Uji Multikolinieritas}

Hasil Uji Multikolinieritas

\section{Coefficientsa}

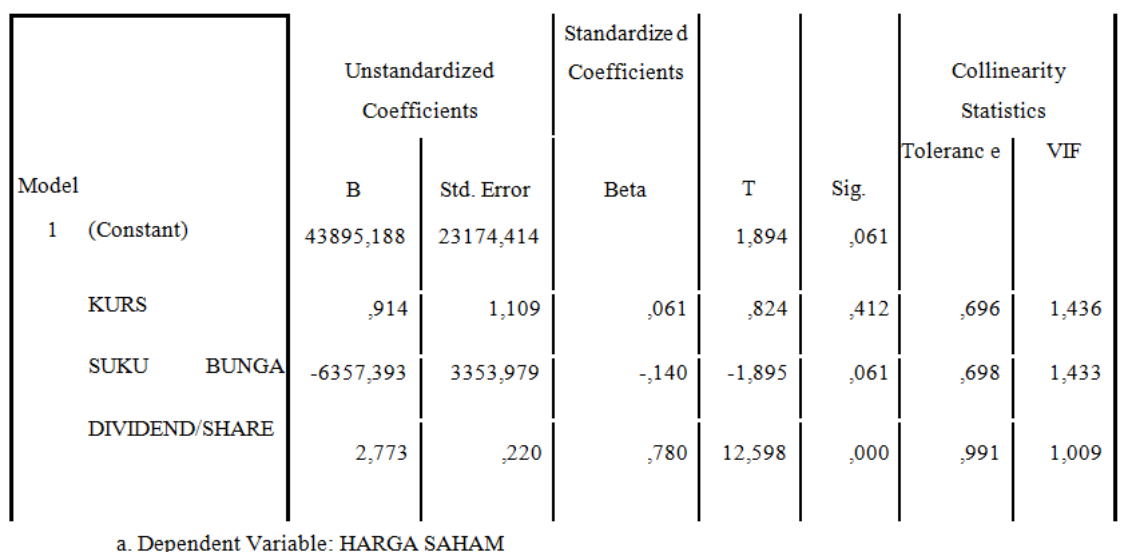


Dari tabel diatas, hasil uji multikolinieritas terlihat bahwa nilai Tolerance variabel kurs (X1) sebesar 0,969, Suku Bunga (X2) sebesar 0,698, dividen pershare (X3) sebesar 0,991 . Sedangkan hasil perhitungan nilai VIF variabel kurs (X1) sebesar 1,436, suku bunga (X2) sebesar 1,433, dividen pershare (X3) sebesar 1,009. Semua variabel independen dalam penelitian ini mempunyai nilai tolerance diatas 0,10 dan nilai VIF kurang dari 10, hal ini data disimpulkan bahwa regresi terbebas dari asumsi multikolinieritas.

\section{Uji autokorelasi}

Hasil Uji Autokorelasi

Model Summary ${ }^{b}$

\begin{tabular}{|c|c|c|c|c|c|c|c|c|c|c|}
\hline \multirow[t]{2}{*}{ Model } & \multirow[t]{2}{*}{$\mathrm{R}$} & \multirow{2}{*}{$\begin{array}{c}\mathrm{R} \\
\text { Square }\end{array}$} & \multirow{2}{*}{$\begin{array}{l}\text { Adjusted } \\
\text { R Square }\end{array}$} & \multirow{2}{*}{$\begin{array}{l}\text { Std. Error } \\
\text { of the } \\
\text { Estimate }\end{array}$} & \multicolumn{5}{|c|}{ Chane Statistics } & \multirow{2}{*}{$\begin{array}{l}\text { Durbin } \\
\text { Watson }\end{array}$} \\
\hline & & & & & $\begin{array}{c}\mathrm{R} \\
\text { Square } \\
\text { Change }\end{array}$ & $\begin{array}{c}F \\
\text { Change }\end{array}$ & $\begin{array}{c}\text { Df } \\
1\end{array}$ & Df2 & $\begin{array}{l}\text { Sig.F } \\
\text { Change }\end{array}$ & \\
\hline 1 &, $785^{\mathrm{a}}$ & ,616 & ,605 & ,43678 & ,616 & 54,036 & 3 & 101 &, 000 & 2,230 \\
\hline
\end{tabular}

a. Predictors: (Constant), DIVIDEND/SHARE, SUKU BUNGA, KURS

b. Dependent Variable: HARGA SAHAM

Berdasarkan tabel diatas, diketahui nilai Durbin Watson sebesar 2,230 dengan membandingkan nilai tabel signifikan $5 \%$, jumlah sampel $n=21$ dan jumlah variabel independen $=3$, maka diperoleh dL (batas bawah DurbinWatson) sebesar 1.0262 dan dU (batas atas Durbin-Watson) sebesar 1,6694. (4$\mathrm{du})=(4-1,6694)=2,3306$ sehingga pengambilan keputusannya adalah dU < $\mathrm{dW}<4-\mathrm{dU}$ atau $1,6694<2,230<$ 2,3306 maka dapat disimpulkan bahwa dalam penelitian ini tidak terjadi autokorelasi.

\section{Uji Heteroskedastisitas}

Hasil Uji Heteroskedastisitas

Scatterplot

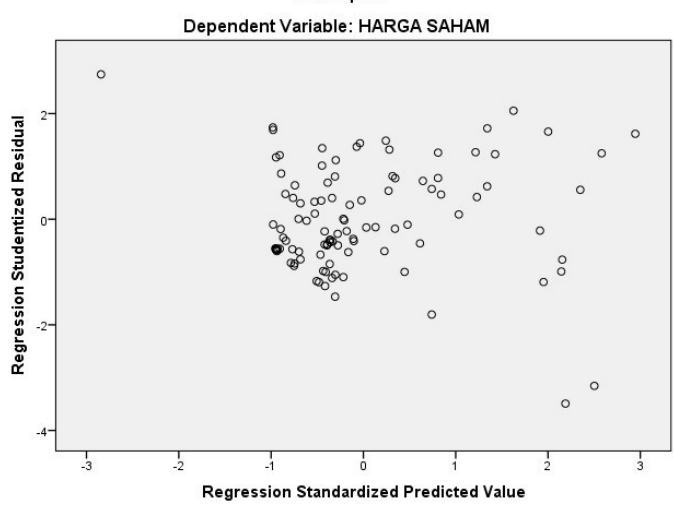

Dari grafik scatterplot dilihat bahwa titik menyebar secara acak serta tersebar diatas maupun dibawah angka 0 pada sumbu Y. Hal ini dapat disimpulkan bahwa terjadi heteroskedastisitas pada model regresi.

\section{Analisis regresi linier sederhana}

\section{Hasil Regresi Linier Sederhana kurs/nilai tukar rupiah terhadap harga saham}

Coefficients $^{\mathrm{a}}$

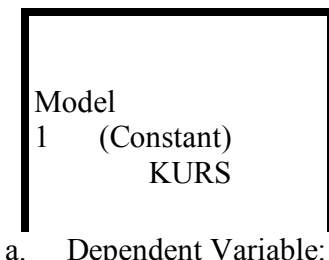

Unstandardized Coefficients

\begin{tabular}{c|c} 
B & Std. Error
\end{tabular}

$$
\begin{array}{l|r}
-3802,584 & 6686,512
\end{array}
$$

a. Dependent Variable: HARGA SAHAM

$$
\mid
$$

Standardized

Coefficients Beta 
Dari hasil perhitungan analisis regresi linier sederhana kus/nilai tukar rupiah terhadap harga saham menunjukan bahwa nilai t hitung sebesar 0,892 dan $\mathrm{t}$ tabel sebesar 2,086 $(0.892<2,086)$ maka Ho diterima. Artinya kurs tidak berpengaruh dengan harga saham. Sedangkan tingkat (sig) sebesar $0,375>0,05$ artinya tidak signifikan. Hal tersebut membuktikan bahwa kurs tidak berpengaruh dan tidak signifikan terhadap harga saham.

\section{Hasil Regresi Linier Sederhana Suku Bunga Terhadap Harga Saham}

\begin{tabular}{|c|c|c|c|c|c|}
\hline & & oefficients ${ }^{a}$ & & & \\
\hline & Unstandardized & oefficients & $\begin{array}{r}\text { Standardized } \\
\text { Coefficients }\end{array}$ & & \\
\hline Model & B & Std. Error & Beta & & \\
\hline 1 (Constant) & 4103,590 & 1399,867 & & 2,931 & ,004 \\
\hline SUKU BUNGA & $-30710,277$ & 21438,329 &,- 140 & $-1,432$ & , 155 \\
\hline
\end{tabular}

a. Dependent Variable: HARGA SAHAM

Dari hasil perhitungan analisis regresi linier sederhana suku bunga terhadap harga saham menunjukan bahwa $\mathrm{t}$ hitung sebesar - 1,432 dan $\mathrm{t}$ table sebesar 2,086 $(-1,432<2,086)$ maka Ho diterima. Artinya suku bunga tidak berpengaruh terhadap harga saham. Sedangkan tingkat (sig) $0.155>0.05$ artinya tidak signifikan. Hal tersebut membuktikan bahwa suku bunga tidak berpengaruh dan tidak signifikan terhadap harga saham.

\section{Hasil Regresi Linier Sederhana Dividen pershare terhadap Harga Saham}

\begin{tabular}{|c|c|c|c|c|c|c|}
\hline & & efficients ${ }^{\mathrm{a}}$ & & & \\
\hline \multicolumn{2}{|c|}{ Model } & Unstandardize & Coefficients & $\begin{array}{l}\text { Standardized } \\
\text { Coefficients }\end{array}$ & $t$ & Sig. \\
\hline 1 & (Constant) & $\begin{array}{l}\mathrm{R} \\
439,643\end{array}$ & $\begin{array}{l}\text { Std Frrnr } \\
276,961\end{array}$ & Beta & 1,587 & 115 \\
\hline & DIVIDEND/SHARE & 9,522 & 887 & ,727 & 10,735 & ,000 \\
\hline
\end{tabular}

a. Dependent Variable: HARGA SAHAM

Dari hasil perhitungan analisis regresi linier sederhana dividen pershare terhadap harga saham menunjukan bahwa $\mathrm{t}$ hitung sebesar 10,735 dan $t$ tabel sebesar 2,086 (10,735>2,086) maka Ho ditolak. Artinya dividen pershare berpengaruh terhadap harga saham. Sedangkan tingkat (sig) $0.000<0.05$ artinya signifikan. Hal tersebut membuktikan bahwa dividen pershare berpengaruh dan signifikan terhadap harga saham.

\section{Analisis regresi berganda}

Hasil Analisis Regresi Linier Berganda

Coefficients $^{\mathrm{a}}$

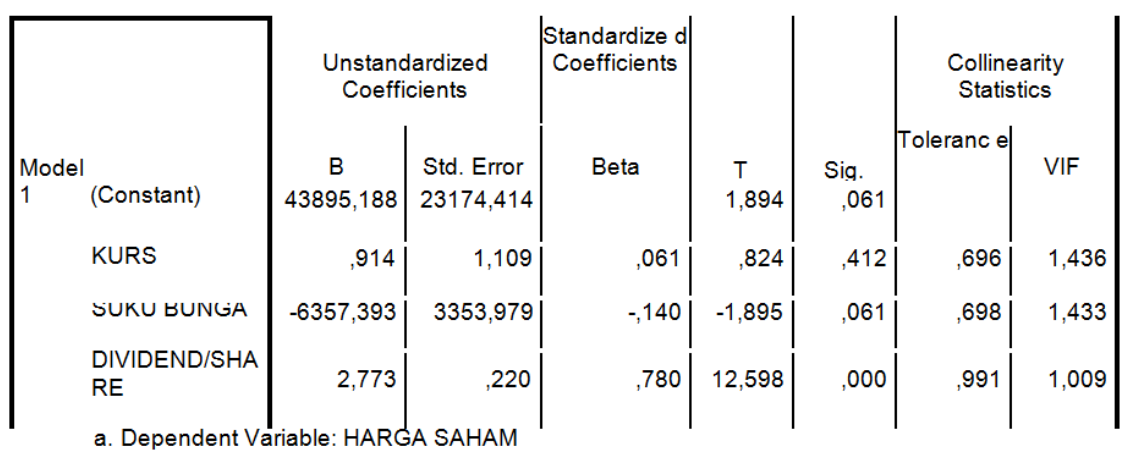


Berdasarkan persamaan regresi linier berganda didapat persamaan yang $\operatorname{diatas} \mathrm{Y}=43895,188+0,914$ $6357,393+2,773+\mathrm{e}$

Diminta :

$$
\mathrm{Y}=\text { Variabel harga saham }
$$

\section{Uji sig. Koefisien regresi berganda}

\section{Hasil Uji Signifikansi Koefisien Regresi Berganda}

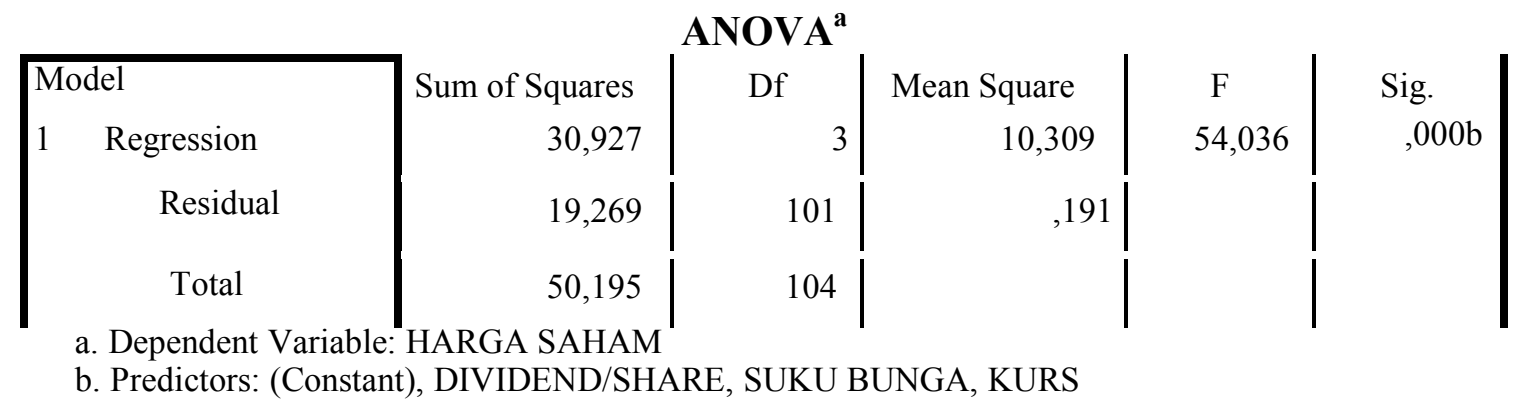

Dari analisis diatas dapat diketahui nilai signifikansi regresi linier berganda sebesar 0.000 karena nilai sig $0.000<$ 0.05 maka dikatakan bahwa kurs/niali

$$
\begin{aligned}
& \mathrm{X}_{1}=\text { kurs/nilai tukar rupiah } \\
& \mathrm{X}_{2}=\text { suku bunga } \\
& \mathrm{X}_{3}=\text { dividen pershare } \\
& \mathrm{e}=\text { error }
\end{aligned}
$$

\section{Koefisien determinasi}

\section{Hasil analisis koefisien determinasi (R Square)}

Model Summary

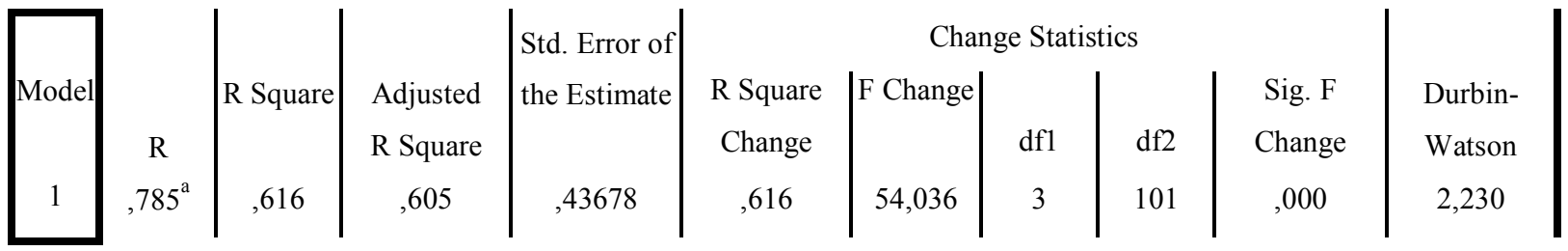

a. Predictors: (Constant), DIVIDEND/SHARE, SUKU BUNGA, KURS

b. Dependent Variable: HARGA SAHAM

Dari hasil perhitungan tabel diatas, dapat diketahui nilai sebesar 0,616. Nilai tersebut mengandung arti bahwa total variasi harga saham disekitar rataratanya $61,6 \%$ dapat dijelaskan melalui hubungan antara kurs, suku bunga, dan dividen pershare secara bersama-sama. Sedangkan sisanya 38,4\% dipengaruhi oleh faktor lain yang tidak dapat dijelaskan.

\section{KESIMPULAN DAN SARAN}

Berdasarkan hasil analisis data dan pembahasan yang telah dikemukakan maka dapat diambil beberapa kesimpulan sebagai berikut : 1) Hasil penelitian ini menunjukkan bahwa kurs/nilai tukar memiliki pengaruh dan tidak signifikan secara parsial terhadap harga saham sektor perbankan periode 2013-2017. 2) Hasil penelitian ini menunjukkan bahwa suku bunga berpengaruh dan tidak signifikan secara parsial terhadap harga saham sektor perbankan periode 2013- 
2017. 3) Hasil penelitian ini menunjukkan bahwa dividen pershare berpengaruh dan signifikan secara parsial terhadap harga saham sektor perbankan periode 2013-2017. 4) Hasil penelitian ini menunjukkan bahwa kurs/nilai tukar, suku bunga, dan dividen pershare berpengaruh dan signifikan secara simultan terhadap harga saham sektor perbankan periode 2013-2017

\section{Saran}

Setelah mengkaji hasil penelitian ini maka saran yang dapat penulis ajukan adalah sebagai berikut: Untuk perusahaan sebaiknya memperhatikan aspek Dividend Per Share (DPS) karena sesuai dengan penelitian ini DPS dapat menjadi acuan bagi investor dalam memilih saham perusahaan perbankan yang ada di Bursa Efek Indonesia. Hal ini terjadi karena para investor cenderung untuk memilih perusahaan yang mampu menghasilkan keuntungan dimasa mendatang. Penelitian ini hanya terbatas pada beberapa rasio-rasio keuangan yang mempengaruhi harga saham pada perusahaan perbankan di Bursa efek Indonesia. Untuk peneliti selanjutnya diharapkan untuk menambah variable variabel lain yang mempengaruhi harga saham dan memperpanjang periode penelitian agar jumlah sampel yang didapat lebih banyak dan mampu menghasilkan penelitian yang lebih baik.

Banyak faktor yang mempengaruhi penentuan harga saham antara lain tingkat suku bunga dan nilai tukar. Untuk itu bagi para investor yang akan berinvestasi saham harus benar-benar teliti ketika akan membeli saham.

\section{DAFTAR PUSTAKA}

Anoraga, Pandji dan Pakarti, Puji 2008 "Pengantar Pasar Modal” Penerbit Rineka cipta

Atik, Yopi Atul Imrpoh. 2012. Pengaruh Inflasi, Nilai Tukar, dan Tingkat Suku Bunga SBI terhadap Harga Saham Perbankan yang Terdaftar di Bursa Efek Indonesia. Fakultas Ekonomi, Universitas Gunadarma, Jakarta. Bank Indonesia. 2013.

Data BI Rate, diakses pada tanggal 12 Februari 2016 dari http:/www.bi.go.id/$\mathrm{id} /$ moneter/bi-rate/data/Default.aspx

Ekonomi Uang 2010, Perbankan, dan Pasar Keuangan. Edisi 8. Buku 1. Jakarta: Salemba Empat.

Ghozali, Imam. 2005. Aplikasi Analisis Multivariate dengan Program SPSS, Semarang: BP - UNDIP.

H. Mudasetia. 2008. "Pengaruh suku bunga deposito dan kurs terhadap harga saham pada industri perbankan. Jurnal Ekonomi \& Pendidikan, Volume 5 Nomor 2, Desember 2008

Laporan keuangan http://www.idx.co.id/perusahaan-tercatat/laporan-keuangan- dantahunan/ (5 Juni 2018)

Lubis, Irhan Fauzi. 2010. Pengaruh Tingkat Suku Bunga dan Nilai Tukar Terhadap Harga Saham Perbankan di Bursa Efek Indonesia. Magister Manajemen, Universitas Terbuka, Jakarta.

Manurung, J., dan Manurung, A.H. 2009. "Ekonomi Keuangan dan Kebijakan Moneter". Jakarta: Salemba Empat. 
Maryanti, Sri. 2009. Analisis Pengaruh Nilai Tingkat SBI dan Nilai Kurs Dollar AS terhadap Indeks Harga Saham Gabungan (IHSG) Studi Pada Bursa Efek Jakarta. Pekbis Jurnal, Vol.1, No.1, Maret 2009 : 12-25

Mishkin, F.S. 2008. "Ekonomi Uang, Perbankan, dan Pasar Keuangan. Edisi 8. Buku 2". Jakarta: Salemba Empat.

Nainggolan, K., Soekardono., dan Hanani, N. 2005. “Teori Ekonomi Makro”. Edisi Pertama. Bantul: Pondok Edukasi.

Kurs/nilai tukar rupiah, https://www.bi.go.id/id/moneter/informasi-kurs/transaksibi/Default.aspx (5 Juni 2018)

Putong, Iskandar. 2013 “Econimics pengantar mikro dan makro”. Edisi kelima. Jakarta

Raharjo, Sugeng. "Pengaruh Inflasi, nilai kurs rupiah, dan tingkat suku bunga terhadap harga saham di BEI”STIE “AUB” Surakarta

Ratna, Maria, Topowijoyo, Sulasmiyati, 2006 "Pengaruh tingkat suku bunga, nilai tukar, dan inflasi terhadap harga saham” Jurnal Administrasi Bisnis (JAB)|Vol. 35 No. 2 Juni 2016

Sugiono. 2006, "Metode penelitian Kuantitatif Kualitatif dan R\&D”. Jakarta Sugiyono. 2006. "Metode Penelitian Administrasi. Bandung : Alfabeta Sugiyono, 2013. "Metode Penelitian Bisnis". Bandung : Alfabeta

Sunariyah, 2000. Pengantar Pengetahuan Pasar Modal. UPP APM YKPN. Yogyakarta.

Supranto, J, 1997, Statistik: Teori dan Aplikasi. Jakarta: Erlangga. Surakhmad, Winarto. 1990. Pengantar Penelitian Ilmiah, Bandung, Tarsito Tandelilin, Eduardus. 2010. Portofolio dan Investasi Teori dan Aplikasi: Edisi Pertama. Yogyakarta: Kanisius.

Yogi. 2008 "Pengaruh inflasi, nilai tukar,, dan tingkat suku bunga SBI terhadap harga saham perbankan yang terdaftar di Bursa Efek Indonesia (BEI). Jurusan Manajemen Fakultas Ekonomi Universitas Gunadarm 